\title{
Religious Multiplicity: An Inquiry into the Psychological Use/Abuse of the Social Media in Evangelism
}

\author{
Umeogu, Bona Christus, Ph.D , Onebunne Jude Ifeanyichukwu, Ph.D² \\ Ojiakor, Caroline Ifeoma, Ph.D ${ }^{3 *}$ \\ ${ }^{1,2}$ Department of Philosophy, Nnamdi Azikiwe University Awka, Anambra State, Nigeria. \\ ${ }^{*}$ Department of Mass Communication, Imo State University Owerri, Nigeria. \\ bonachristus_umeogu@gmail.com/juno.anyi@gmail.com/ojiakor99@gmail.com
}

\begin{abstract}
This study explored the confluence of psychological and media communication metaphor exploited in religious persuasion by $21^{\text {st }}$ century church leaders in the use and abuse of social media communication for religious worship. Typically, the study contrasts the truism that religious abuse of social media communication in propagating false spiritualism has diminished the merits of social media as the greatest breakthrough of information and communication technology (ICT) as a tool in religious evangelism. The study conceptualizes that the versatility of the social media has also deepened the thrust of religious evangelism positively, and negatively. Against this background, Rashdall's (1907) "moral criterion" in the use of the Theory of good and evil gifts this current examination the philosophical underpinnings of man's vulnerability in exploiting nature's endowments and human development for both psychological hedonism and rationalistic utilitarianism. In the case of the use/abuse of the social medial for religious evangelism, there is a strong conformity of opinions to the fact that under the current circumstances of uncontrollable high-tech falsehood; man's free-will in the choice of his actions and the gift of reasons and feelings above any other animal leads to the conclusion that human advancements (such as social media) should lead man to a better life despite volumes of spiritual falsehood communicated through those platforms.
\end{abstract}

Keywords: Communication, falsehood, evangelism, information-technology, spiritualism, psychology, social media

\section{INTRODUCTION}

From the earliest time, religion served man a glorious path helping him forge his path (spiritual) to his Creator. In all the struggles toward civilization and toward better civilization, religion has been invariably present (Coe, 1904). Its importance stems from its ability to bridge together the material and the immaterial world, helping followers appraise the supremacy of the latter through faith especially in understanding complex reality of their being, existence and death. This element made it opium without intoxication.

On religious evolution, Bidney (1954) contended that the evolution of human civilization and developmental advancement has patterned religious traditions and practices as much as they have in the opinion of McClure (2017) influenced its uses and application within contextual circumstances. These developmental influences as we witness now in the use of the internet and social media are some of the reasons for religious multiplicity and relativism (Woodhead, 2016; King, 2011) orchestrating in most unholy circumstances: religious exclusiveness (Ellman, 2000), radicalism, fanaticism and even worse (Schmidt, 2018; Birdsall \& Collins, 2017) with the latter becoming the greatest exploit in the hands of unscrupulous elements hiding in the dark corners of the internet/ social media to sell religious falsehood and anti-spirituality to unsuspecting soul searching worshippers.

Despite this unfortunate circumstance diminishing the merits of the internet and social media in faith propagation, the gains of Information and Communication Technology (ICT) as one of the greatest tool in religious evangelism remain untarnished. Hither-to, the media has served as veritable platform for propagating religious faith and spirituality especially in reaching wider audience either in print, radio or television broadcast or through the 
World Wide Web - the internet. Media's ability to reach phenomenal number of audience faster than usual without the pain of human-driven evangelism is its appeal for users and abusers. In this ensuing contrast, the authors utilized Rashdall's (1907) Theory of good and evil applying the relevance of "moral criterion" to depict web 2.0 popularly called the social media as a two-edged sword which has abetted users and abusers with the psychological advantage over their social media audience with the later exploiting this advantage in propagating spiritual falsehood.

\section{REVIEW OF RELATED LITERATURE}

\section{Religious Multiplicity}

Many visions of God abounds; so also, the path towards Him (McKim, 2012). The human evolution is somewhat universal and has influenced all spheres of life including religion. As Heim (2006) posits, diversity is the ultimate religious end because religious multiplicity or pluralism is both a consequence of human evolution as much as it is the evolution itself. Broadly construed, multiplicity is a response to the diversity of religious beliefs, practices, and traditions that exist both in the contemporary world and throughout history. The term multiplicity can either be canonical in meaning and truth or denominational in practice but both symbolize distinct differences in belief, faith, practice, worship and religious culture. What has been problematic is the intent and purposes of new religious faiths or denomination.

In views of Bogardus (2013), many religious beliefs are held due to contingent factors irrelevant to the truth or warrant of the beliefs. Bogardus' attempts hint us of possible wrong motive and cause of religious multiplicity relying on invalid logical inferences; a possibility that could underline psychological falsehood in faith worship. Against this, Shimazono (2011) argued that such circumstance may be heightened in the presence of digital world given the privacy and anonymity the internet and social media portends especially for faith regulation.

Furthermore, because disciplinary commitments differ philosophically and theologically, treatments of religious diversity have generally adopted different attitudes and different methods regarding the understanding thereof in respect to faith commitments particularly of religious traditions such as Christianity with the "Abrahamic" religions or of Islam and practices of other traditions. While philosophical and theological accounts tend to adopt more focus on methodological and perspectival differences respectively in epistemological or ethical issues raised by religious diversity (Norton, 2007) which raises questions about the justification of conflicting religious beliefs that have received much attention in analytic literature; both accounts inform and influence each other and the differences have made multiplicity in faith and logic a growing chain further propelled by the awesome power of the media especially the internet.

\section{Religion and Digital Age Evangelism}

Religion has not been achieved as a result of culture, nor has it waited for maturity in the individual any more than for maturity in the race but, is a part of culture at every stage of human history (Coe, 1904). The reality of religious pluralism is undeniable especially on the heels of man's continuous search for God, hope, salvation and the interconnectedness of religion with socio-political, socio-cultural and more recently, socio-economic influence (Adogame, 2016). These antecedents in view of religious development and followership have yielded positive fruits (in Nigeria) leading to rapid evangelization of remotest parts of the country albeit its negative nuances perennially plaguing its spiritual essence (Bidwell, 2015). The dyadic nature of its fruits (rapid evangelization and spiritual essence) in consideration of the experiences of Nigerians no doubt presents our generation of worshippers with new challenges and concerns especially of the motives of evangelism.

Many cases abound where the spiritual essence is neglected and materialism becomes evident in religious worship (Gilbert, 2015; King, 2011). This is in the wake of many religious denominations whether virtual or physical becoming a marketplace with an assurance of God's providence a bet over all human suffering if one sowed a seed or parts with his/her finances, a falsehood bought by many (Chiluwa, 2013). The latter is a 
common antithesis of new age spirituality albeit the true search for God and personal salvation. As much as this problem is real and is the concern of many genuine religious leaders; the pace of evangelism experience in this age through the utilization of info-technological breakthroughs cannot be compared to age in history. These breakthroughs have in essence contributed immensely in winning of souls, bringing hope to the hopeless, and expanding the frontiers of evangelism much faster and rapidly. Perhaps, the greatest gift of media is that despite the noise in the digital space, the presence of religion in the technological space has remained a conscience for many even as it is dead in many anti-God movements parading themselves as religious worships.

\section{Nigeria and Religious Evangelism}

Nigeria as a nation through the prism of religious history and its interconnectedness with culture, social life and politics is a thriving one with huge harvest spiritually and otherwise. The contestation of ritual, social space and power in Nigeria's socio-religious economy and its negotiation and self-insertion into the global religious marketplace is one which has attracted attention. The domination of Christianity and Islam in Nigeria can be better appreciated in relation to the use of religion as religio-political capital evidence in the divisiveness of the country even as this problem is universal class struggle for power and domination (Chiluwa, 2013). Under this very circumstance, religious use and abuse in Nigeria both by the clergy and the common man connotes several altercations than the reality.

Consider that good as religion may be, there is growing concern that many perfidious acts perpetrated in the name of God and religion have reached abysmal proportions among unsuspecting worshippers. There are several cases of impersonation of the religious leaders and/or clergy men to defraud unsuspecting worshippers. Many cases also abound of real and fake clergymen and women who have obtained in false pretence, others such as; advanced fee fraud for prayers and religious sacrifices, money for prayers and monetized rituals in the church speaks volumes of religious abuse (Gilbert, 2015). In the wake of these challenges, scholars interests has grown regarding various forms of abuse using religious nomenclature and how this affects the spiritual lives of the unsuspecting worshippers. There is even greater concern that this digital age, if it has a disadvantage, has had its anonymity of "plug and play" harnessed for serial abuse in what may be termed commercialization of religious worship not minding however, its antecedent promotion of evangelical mission to a greater height. The current study therefore is an effort to examine how the use and abuse of the social media has abetted at least, theoretically, the prevalence of religious multiplicity using Rashdall's (1907) Theory of good and evil which supports that its use or abuse is a conscious and premeditated act bordering on conscience.

\section{Internet, Media and Evangelism}

The reach at religious worshippers and converts has always evolved from the times of epistle writing during the first century AD to our current digital age. Technologically driven developments such as the print media, radio, television and now the internet have redefined the nature of religious evangelism to something rapid in its outreaching ability. Although, the Internet technology presents a new conceptual reality, one that could potentially challenge religion in subtle but distinct ways; few sociologists of religion, however, have attempted to evaluate whether using the Internet impacts the way people think about and practice religion (McClure, 2017). Data from Baylor Religion Survey (2010) suggests that the Internet use affects how people think and affiliate with religious traditions which is associated with increases in being religiously unaffiliated and decreases in religious exclusivism. Baylor's (2010) study confirms McClure's (2017) finding that television viewing of religious programs is linked to decreases in religious attendance and other time-related religious activities; something that help create anonymity between the presiding clergy and the viewing worshippers. This element is what have been harnessed using online streaming audio or video and real-time online broadcasting channels to have even greater effects on the audience and viewers. This versatility of the internet especially in the use of social media has also deepened the thrust of religious evangelism both positively, and negatively. 
Positively, the media has aided wider coverage of religious to reach subtle ends of earth and has helped to provide spiritual succour to people without access to physical religious worship either due to lack of it or unfavourable conditions. Downey (2014) contended that the Internet platforms (audio, video and instant messages) have increasingly helped to increase the chances of personal and individual soul upliftment and religious encounter a possibility. These encounters (online worships) in the views of McClure (2017) have provided privacy and comfort which are positive aspects of the Internet which have kept its users glue. In some circumstances, the privacy and comfort the Internet provides has become its bane with devastating consequences as some unscrupulous elements exploit its anonymity to perpetuate varying degrees of socio-religious falsehood.

Regrettably, the gains of the internet and social media have been lost in the disillusionment caused by the brazen abuse by both the clergy and impostors who have deployed the privacy of the platform for commercialization of religious worship (Resane, 2017; Gilbert, 2015; Chiluwa, 2012; 2013). Chiluwa's (2012) study on online religion in Nigeria: the internet church and cyber miracles revealed that the positive characteristics of the Internet platform have been exploited to mislead unsuspecting worshippers for commercial gains. These, the author referred to as, the propagation of cyber miracles. In support to the Chiluwa's (2012) contention, Gitonga (2011, cited in Resane, 2017) asserted that commercialization of the gospel could be the presentation of the biblical message either as a commodity for sale for material gain or as an object of investment for personal aggrandizement. According to Resane, the former refers to the sale of spiritual benefits, such as spiritual healing and offer of prayers for special needs while latter refers to the donation of money or item(s) to the Church with an expectation that God will repay much more in return. There is also outright abuse of prophecy which has been used falsely at the expense of worshippers. Others include breach of trust and confidence placed on religious leaders in ways scandalous and dehumanizing. It is noteworthy, that these commercial endeavours which are mostly undertaken through technology (although, they have rapidly spread to the physical church also), exerts its negative influence on the evangelical world, especially spreading from the America and the Western world to other parts of the globe in general.

Despite these abuses in forms and manners highlighted above, many testimonies have been recorded on various digital platforms where the faith in God, redemption, healing, forgiveness and upliftment of souls are ever present. These contrasts present a daunting question on; what is the motive of use or abuse of the social media in religious evangelism? The answer to this question may be only be found in Rashdall's (1907) Theory of good and evil which gifts this current study the understanding of the philosophical underpinnings of man's vulnerability in exploiting nature's endowments and human development for perpetuation of psychological hedonism and rationalistic utilitarianism bringing "moral criterion" to the foreground.

\section{CONCEPTUAL FRAMEWORK}

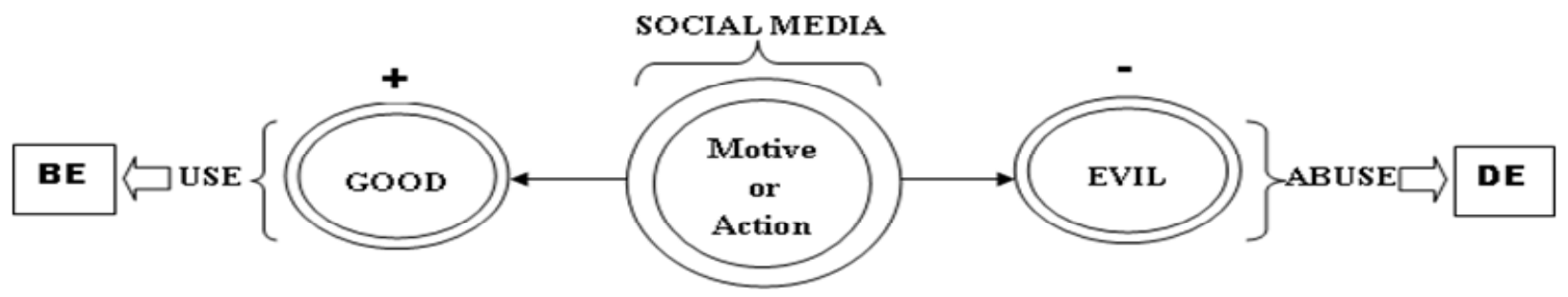

Fig1. Conceptual model of the study illustrating the application of Rashdall's (1907) theory of Good and evil and its application in use and abuse of the social media for religious evangelism

Source: Authors, 2018.

KEY: USE $=+$ Positive deployment of social media breeds Beneficial Evangelism (BE) influence by motive/ action, ABUSE = - Negative deployment of social media breeds Destructive Evangelism (DE) influenced by motive/action 
From the conceptual model in Figure 1, a graphical representation of the application of Rashdall's (1907) Theory of Good and Evil is made. From the illustration, it is conceptualized that the motive of user and the consequent action ensuing from those motives determines his/her utilization of the social media platform as a tool for evangelism. If the motive is positive in this case "good" then, the deployment of social media platform will be useful leading to beneficial evangelism unleashing miracles, salvation and hope despite the distant; otherwise, when the motive is negative in this case "evil", the deployment of the social media platform will end up in abuse something that breeds destructive evangelism such as commercialization of worship of God and exploitation of the church followers.

\section{THEORETICAL FRAMEWORK}

\section{Theory of Good and Evil (Rashdall, 1907)}

Rashdall (1907) proposed using the Theory of Good and Evil that under moral criterion, motive of an action and the consequences of such action determine its essence/value which summarily can either be termed "good" or "evil". Perhaps, Rashdall's greatest work in ethics is summed up in this simple but elaborate theory. Rashdall's proposition maintained that there are pressures in terms of both pleasure and virtuous disposition in what he referred as "ideal utilitarianism" which gifts scholars to understand that actions serve to satisfy the motives and the outcome either good or evil is satisfaction of the performer.

In the current study, Rashdall's propositions have been found useful in explaining the dichotomous circumstances which have seen the deployment of the Internet and social media in the propagating of religious faith and evangelism a contrasting metaphor whose abuse by religious leaders and impostors has questioned the value of its actual use. Rashdall's theory makes us understand that the outcome of social media deployment in religious evangelism is dependent on the motive which will define its use or abuse either as "good" or "bad" respectively. For instance, if evangelism is commercialized because of financial, social and political gains, then the deployment of social media in such evangelical mission is abuse, something whose eventual outcome is evil whereas if it is desired to win greater souls for God through wider reach, bring succour to the poor, hope to the hopeless about salvation to sinners, then its proper use has been deployed with a positive outcome ultimately ending in "good" as depicted in the conceptual model.

\section{Implications of the Study Finding}

The current inquiry into the psychological use/abuse of the social media in evangelism on the heels of religious multiplicity poses significant implication on the human religious evolution. Critically, with more economic, social, and political power associated with new age religious evangelism, there is danger that the pursuit of the latter will increase social media abuse in what will remain doom for the audience. There is also the danger that some unscrupulous elements whose motive is destructive might have in pursuit of economic, social and political power seized the social media opportunity to dampen peoples' conscience and morals leading to humanitarian tragedy. This tragedy no doubt will rear their ugly heads in various forms challenging collective efforts towards better living and societal development in many unprecedented forms. Another grievous implication to this study is that without guidance many a soul has been lost to falsehood propagated through social media platforms in what is now known as the digital church without conscience and morality.

\section{RECOMMENDATION}

Weighing the consequences of the social media abuse in religious evangelism especially were the intent or motive of the user is evil; there is need that religious leaders design programs aimed to sensitizing their members on the dangers of patronizing internet religious hawkers without scrutinizing the intent and validity of faith they evangelize. Church leaders by this study are encouraged to provide online presence for the teeming faithful to 
reduce the chances of their subscribing to unscrupulous elements hiding in the dark corners of the internet to wreck spiritual havoc. It is further recommended that religious leaders rise to the occasion to checkmate the arbitral use of their identity by impostors to abuse the social media evangelism.

\section{CONCLUSION}

The complexity of human life, the truism about good and evil and the reality of death have shaped man's search for God since creation. Religion became a necessity to this end and ever since has evolved with man through the ages even in the current digital age of science. How science has aided man in religious worship remain something of unpleasant metaphor. Science as much as it increased the reach and scope of evangelism, it has also potential destructive application owing to its anonymity and personalized influences. Amidst this chaos, the current study explored the possibility that its (social media as an outcome of scientific breakthrough) abuse in manners such as commercialization of faith through to unsuspecting worshipper through the easy to reach/ access media, deceit or fraud may not have entirely diminished the gains of its uses. Consequently, the study utilized the propositions of Rashdall's Theory of Good and Evil to demonstrate that the use and abuse of the social media is something dependent on the motive of the user to either promote good or evil.

\section{REFERENCES}

1. Adogame, A. (2010) How God became a Nigerian: Religious impulse and the unfolding of a nation. Journal of Contemporary African Studies, 28(4), 479-498.

2. Adogame, A. (2016) African Christianities and the politics of development from below. HTS Teologiese Studies / Theological Studies 72(4), 129-144.

3. Bidney, D. (1954). The ethnology of Religion and the Problem of Human Evolution. American Anthropologist, 56(1), 1-18.

4. Bidwell, D. R. (2015). Deep Listening and Virtuous Friendship: Spiritual Care in the Context of Religious Multiplicity. Buddhist-Christian Studies, 35(1), 3-13.

5. Birdsall, J., \& Collins, D. (2017). Reconsidering Religious Radicalism: An Introduction to the Summer 2017 Issue. The Review of Faith \& International Affairs, 15(2), 1-4.

6. Bogardus, T. (2013). The Problem of Contingency for Religious Belief." Faith and Philosophy 30(4), 371-392.

7. Chiluwa, I. (2012). Online religion in Nigeria: The internet church and cyber miracles. Journal of Asian and African Studies, 47(6), 734-749.

8. Chiluwa, I. (2013). Community and Social Interaction in Digital Religious Discourse in Nigeria, Ghana and Cameroon. Journal of Religion, Media and Digital Culture, 2(1), 1-37.

9. Coe, G. A. (1904). Religion as a Factor in Individual and Social Development. The Biblical World, 23(1), 37-47.

10. Downey, A. B. (2014). Religious affiliation, education and Internet use. arXiv preprint arXiv:1403.5534.

11. Ellman, J. (2000). In Defence of a Contented Religious Exclusivism." Religious Studies 36(4), 401-417.

12. Gilbert, J. (2015). The Heart as a Compass: Preaching Self-worth and Success to Single Young Women in a Nigerian Pentecostal Church. Journal of Religion in Africa 45(3-4), 307-333.

13. Gitonga, N. (2011). Commercialization of the Gospel in Africa with particular reference to Kenya: A critique. Kenya Methodist University, 2(2), 117-126. 
Religious Multiplicity: An Inquiry into the Psychological Use/Abuse of the Social Media in Evangelism

14. Heim, S. M. (2006). Salvations: Truth and Difference in Religion. Mayknoll, NY: Orbis.

15. King, K. L. (2011). Factions, variety, diversity, multiplicity: representing early Christian differences for the 21st century. Method \& Theory in the Study of Religion, 23(3-4), 216-237.

16. McClure, P. K. (2017). Tinkering with Technology and Religion in the Digital Age: The Effects of Internet Use on Religious Belief, Behavior, and Belonging. Journal for the Scientific Study of Religion, 56(3), 481-497.

17. McKim, R (2012). On Religious Diversity. New York: Oxford UP.

18. Norton, M.B (2007). Religious Pluralism. Internet Encyclopaedia of Philosophy. University of Arkansas USA: Little Rock.

19. Rashdall, H. (1907). The theory of good and evil: A treatise on moral philosophy 2, Clarendon Press.

20. Resane, K. T. (2017). Commercialization of theological education as a challenge in the Neo-Pentecostal Charismatic churches. HTS Theological Studies, 73(3), 1-7.

21. Schmidt, L. (2018). Cyberwarriors and Counterstars: Contesting Religious Radicalism and Violence on Indonesian Social Media. Asiascape: Digital Asia, 5(1-2), 32-67

22. Shimazono, S. (2011). The many faces of Religious Studies and the multiplicity of religious traditions in Japan. Religion, 41(2), 175-179.

23. Woodhead, L. (2016). Intensified religious pluralism and de-differentiation: the British example. Society, 53(1), 41-46.

Citation: Umeogu, Bona Christus, Onebunne Jude Ifeanyichukwu, Ojiakor, Caroline Ifeoma. "Religious Multiplicity: An Inquiry into the Psychological Use/Abuse of the Social Media in Evangelism" American Research Journal of Humanities and Social Sciences, vol 5, no. 1, 2019, pp. 1-7.

Copyright @ 2019 Umeogu, Bona Christus, Onebunne Jude Ifeanyichukwu, Ojiakor, Caroline Ifeoma, This is an open access article distributed under the Creative Commons Attribution License, which permits unrestricted use, distribution, and reproduction in any medium, provided the original work is properly cited. 